only one glacial period and that the disappearance of palæolithic man from Northern Europe was principally due to the submersion of the greater part of the land beneath the water of an immense freshwater lake or sea, at or a little before the culmination of the ice age. If Mr. Geikie's views should be ultimately accepted, the term " inter-glacial" will be most appropriate; but should, as I hope and believe, mine be proved to be nearer the truth, I should prefer to use the term "pre-diluvial" instead of "pre-glacial," as heretofore, to express the age of palreolithic man.

The Cedars, Ealing, June 22

Thomas BeLT

WIIL you kindly allow me to correct an apparent breach of official etiquette and act of discourtesy in my last week's letter? I should have said that on'y two geologists prominently interested in the question at issue had seen my evidence; for, of course, Mr. H. W. Bristow, F.R.S., Director of the Geological Survey of England and Wales, has been kept fully en rapport with my work, and has several times visited me at Brandon. I am anxious that no statement of mine should appear to slight so eminent a geologist and so considerate a friend.

Brandion

SYDNEY B. J. SKER'TCHLY

\section{Colour-Sense in Birds-Blue and Yellow Crocuses}

UNLESS your readers are quite tired of the subject, may $I$ add a fact which will be subversive of a good deal that has been written about yellow crocuses and sparrows. I dislike yellow crocuses, and four seasons since planted some hundreds of blue and white in the garden underneath my windows. For two seasons they flowered in beautiful profusion. In 1876 the sparrows for the first time destroyed these flowers completely. I allower the roots to remain for another year-viz., I877-but they suffered the same usage, hardly a single flower being left uninjured. So complete was their destruction that I have had the roots dug up.

I regard the proceeding as an imitative one; blue and white crocuses, not being common in the vicinity, were new to the sparrows, and until one more experimental than the rest attacked them they were safe.

A similar result will occur with domestic pigeons; if reared exclusively with small grain, as wheat and barley, they will starve before eating beans. But where they are thus hungry, put a bean-eating pigeon amongst them, and the habit is immediately propagated.

I have seen fowls refuse maize at first, but on seeing others eat it, they follow suit, and become excessively fond of it.

W. B. TEGETMEIER

\section{Purple Verbenas}

HAVING now read for the first time the letters in NATURE regarding the preference that sparrows show for the yellow crocus, it might perhaps help to elucidate the problem were it known that the choice of colour is not only confined to birds, as a few years ago our garden was infested by rabbits and there was a row of eight beds planted in turn, with white, red, and purple verbenas. The flowers of the red and white were eaten close off, whilst those of the purple were never touched. This happened three years running, since which, the garden, being protected by wire netting, has remained undamaged. A. M. DARBY

\section{Japanese Mirrors}

Your correspondents, Messrs. Atkinson, Highley, and Darbishire, have referred to several conjectures and experiments respecting the curious Japanese mirrors and the patterns they reflect. None of these gentlemen have, however, referred to the suggestion offered by Sir David Brewster in the Philosophical Magazine for December, 1832. In this paper Sir David drew attention to some similar phenomena in the light reflected from the surfaces of burnished buttons of metal, arguing that in the mirrors (of which at that time he apparently had seen no actual specimen) there were slight actual inequalities of surface, artificially produced, but concealed from observation by their slightness of depth and by the brightness of the polish. This, of course, may be independent of the particular figures raised in relief on the back, as in the case cited by Mr. Darbishire; and so thought Sir David, for he added :-

"Like all other conjurers, the artist has contrived to make the observer deceive himself. The stamped figures on the back are used for this purpose. The spectrum in the luminous area is not an intage of the figure's on the back. The figures are a copy of the picture which the artist has drawn on the face of the mirror, and so concealed by polishing that it is invisible in ordinary lights, and can be brought out only in the sun's rays."

I trust Mr. Atkinson may be able to learn in Japan the real process of manufacture of these curious toys. Meanwhile are there not specimens in many of our museums that would repay examination? Were there not some amongst last year's exhibits at the Loan Collection of Scientific Apparatus?

SILVANUS P. THOMPSON

University College, Bristol, June 25

\section{NOTE ON THE ELECTRICAL DISTURBANCE WHICH ACCOMPANIES THE EXCITATION OF THE STIGMA OF MIMULUS LUTEUS}

MANY years ago my attention was drawn to the excito-contractility exhibited by the lipped stigma of Mimulus lutezes, the structure of which I then gave an account of in the Proceedings of the Edinburgh Botanical Society. In connection with my recent investigation of the excitatory variation in Dioncea I have, during the last few weeks, in co-operation with $\mathrm{Mr}$. Page, made experiments for the purpose of ascertaining whether in this organ, as in the leaf of Dionce, the change of form provoked by mechanical stimulation is accompanied by a similar electrical disturbance.

Mimulus luteles is a favcurite window plant on account of its showy flowers and the facility with which it can be cultivated. The mechanism of the contraction of the stigma can be best studied in the inferior of the two lobes, of similar size and form, of which the organ consists. In the unexcited state, when the flower is in full bloom, this lobe is curled outwards. The curling outwards is due, as I long ago observed, to the turgidity of the layer of loosely connected conducting cells, ending in papillæ, which constitute the stigmatic surface. So long as this tissue is turgid the elastic lamina by which it is backed is prevented from straightening itself, so that the whole lobe forms a scroll of which the axis is transverse. The effect of touching any part of the lobe, and particularly the papillary surface, is to diminish the turgidity of the tissue, as the result of which the organ slowly expands so as to face and ultimately meet its fellow.

The excitatory change of form which I have described is, as in the case of Dioncea, associated with an electrical disturbance of which the following are the most important features:-(I) The sign of the variation is the same as in Dioncea, the excited structure becomes negative to the rest of the plant. (2) The extent of variation is somewhat less than in Dioncea, the electromotive force developed between the stigma and style being usually about 25-thousandths of a Daniell, whereas in Dionce the variation may amount to from 40- to 50-thousandths. (3) The variation is of relatively long duration; it reaches its maximum at the ordinary temperature of summer, about five seconds after excitation. It subsides at first rapidly, then very gradually, so that the effect may not have entirely passed off until two or three minutes have elapsed.

As in Dionca, the period of electrical disturbance is shortened by increase of temperature. Thus in five stigmas in which the period was measured at $20^{\circ} \mathrm{C}$. $\left(68^{\circ} \mathrm{Fahr}.\right)$ and at $37^{\circ} \mathrm{C}$. ( $\left(98^{\circ} \mathrm{Fahr}.\right)$, the mean duration of the interval of time between the commencement of the electrical disturbance and the moment at which it began to subside was $6^{\circ} 2 \mathrm{sec}$. at the higher temperature, and 3 sec. at the lower. 